\title{
An embolic bow hunter's stroke associated with anomaly of cervical spine
}

Figure $1 \quad$ CT

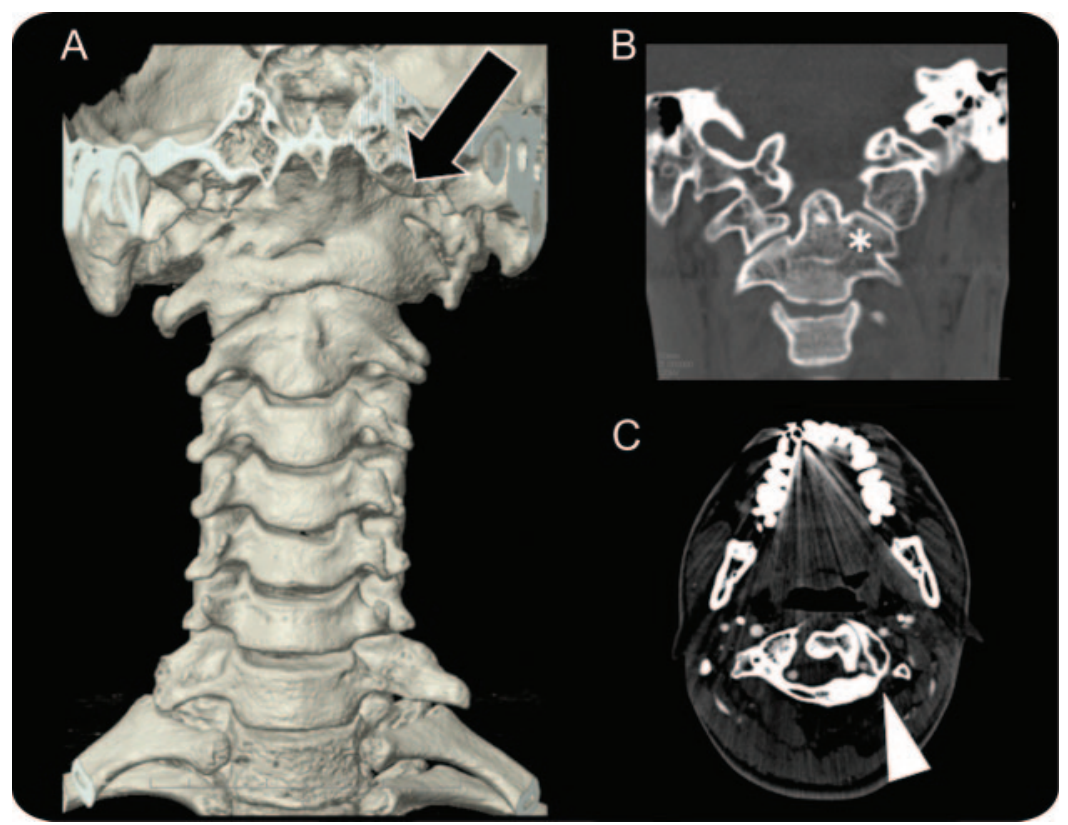

(A) Anterior-posterior view of reconstructed 3-dimensional CT shows occipitalization of the atlas (arrow). (B) Coronal CT depicts a translocated left lateral mass of atlas (asterisk). (C) The 3-dimensional CT angiographic source image demonstrates that left vertebral artery courses through the narrow groove surrounded by the atlas and the translocated lateral mass (arrowhead).

A 16-year-old boy was admitted because of repeated stroke. CT and CT angiography showed abnormalities of cervical spine and left vertebral artery (VA) (figure 1). Cerebral angiography demonstrated that his left VA barely flowed on neck flexion, and thrombotic translucencies indicating thrombus were observed at the stenotic site (figure 2). Transcatheter coil embolization of the left VA was performed, and he has had no recurrences for 10 months. Hemodynamic brain ischemia associated with neck movement was known as bow hunter's stroke. ${ }^{1}$ Abnormal cervical spine can obstruct VA and cause embolic bow hunter's stroke through thrombus formation at the occluded site.

Y. Sakamoto, MD, K. Kimura, MD, Y. Iguchi, MD, T. Iwanaga, MD, H. Toi, MD, S. Matsubara, MD, M. Uno, MD, Kurashiki, Japan

Author contributions: Dr. Sakamoto was the attending doctor of the patient and performed neurologic and imaging examination, prescribed medicines, and made a decision about the patient's management. Dr. Sakamoto prepared this manuscript with other authors' assistance. Dr. Kimura provided scientific advice about anatomy. Dr. Iguchi provided scientific advice about neuroradiologic examinations. Dr. Iwanaga provided scientific advice for the revised manuscript. Dr. Toi provided scientific advice about surgical treatment. Dr. Matsubara provided scientific advice about neurointervention. Dr. Uno provided scientific advice about the pathophysiology.

Disclosure: The authors report no disclosures.

Address correspondence and reprint requests to Dr. Y. Sakamoto, Department of Stroke Medicine, Kawasaki Medical School, 577 Matsushima, Kurashiki City, Okayama 701-0192, Japan; ysakamoto02@gmail.com

1. Sorensen BF. Bow hunter's stroke. Neurosurgery 1978;2:259-261. 

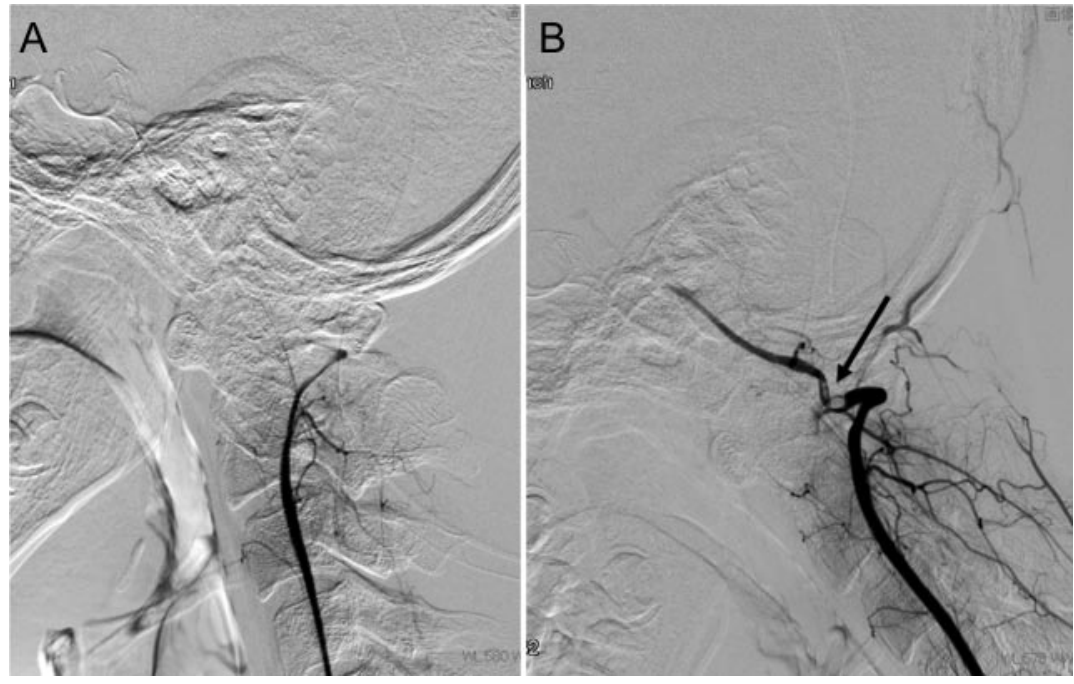

(A) The left vertebral artery is occluded in the neutral head position. (B) The left vertebral artery barely flows on maximum head flexion. Thrombotic translucencies are observed just distal to the stenotic site (arrow).

\section{NeuroImages Are Free at www.neurology.org!}

All Neurology ${ }^{\circledR}$ NeuroImages can now be freely accessed on the Neurology Web site. See them at www.neurology.org, where you can also sign up for journal email alerts and check out other online features, including the Resident \& Fellow section, Neurology: Clinical Practice, and the weekly Neurology Podcasts. 


\title{
Neurology
}

\author{
An embolic bow hunter's stroke associated with anomaly of cervical spine \\ Y. Sakamoto, K. Kimura, Y. Iguchi, et al. \\ Neurology 2011;77;1403-1404 \\ DOI 10.1212/WNL.0b013e31823152f9
}

This information is current as of October 3, 2011

\section{Updated Information \& Services}

References

Subspecialty Collections

Permissions \& Licensing

Reprints including high resolution figures, can be found at: http://n.neurology.org/content/77/14/1403.full

This article cites 1 articles, 0 of which you can access for free at: http://n.neurology.org/content/77/14/1403.full\#ref-list-1

This article, along with others on similar topics, appears in the following collection(s):

All Cerebrovascular disease/Stroke

http://n.neurology.org/cgi/collection/all_cerebrovascular_disease_strok $\mathrm{e}$

\section{Embolism}

http://n.neurology.org/cgi/collection/embolism

Stroke in young adults

http://n.neurology.org/cgi/collection/stroke_in_young_adults

Information about reproducing this article in parts (figures,tables) or in its entirety can be found online at:

http://www.neurology.org/about/about_the_journal\#permissions

Information about ordering reprints can be found online:

http://n.neurology.org/subscribers/advertise

Neurology ${ }^{\circledR}$ is the official journal of the American Academy of Neurology. Published continuously since 1951, it is now a weekly with 48 issues per year. Copyright Copyright (? 2011 by AAN Enterprises, Inc.. All rights reserved. Print ISSN: 0028-3878. Online ISSN: 1526-632X.

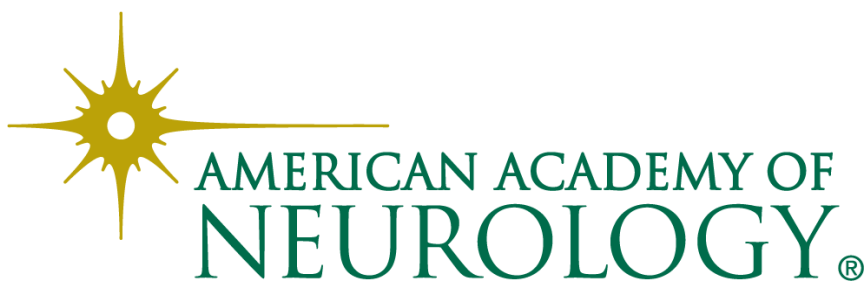

